\title{
Archean Podiform Chromitites and Mantle Tectonites in Ophiolitic Mélange, North China Craton: A Record of Early Oceanic Mantle Processes
}

\author{
Jianghai Li, Department of Geology, Peking University, Beijing 100871 China \\ Timothy M. Kusky*, Department of Earth and Atmospheric Sciences, St. Louis University, St. Louis Missouri 63103, USA \\ Xiongnan Huang, Department of Geology, Peking University, Beijing 100871 China
}

\section{ABSTRACT}

We report 2.5 billion-year-old oceanic mantle podiform chromitite and mantle tectonite in ophiolitic mélange in the North China craton. Tectonic blocks of peridotite, wehrlite, pyroxenite, harzburgitic tectonite, dunite, podiform chromitite, layered gabbro, sheeted dikes, and pillow lava are embedded in a strongly deformed metasedimentary and metavolcanic matrix. The blocks are traceable along strike into the relatively complete ca. 2.505 Ga Dongwanzi ophiolite.

Textures in the ultramafic blocks provide a window into igneous and structural processes active in Archean suboceanic mantle. Chromitites in dunitic envelopes preserve igneous nodular, orbicular, antinodular, banded, massive, and disseminated textures. Dunite envelopes are common features of podiform chromitites, forming almost exclusively in the upper mantle or the crust-mantle transition zone of suprasubduction zone (harzburgite-type) ophiolites of younger geological ages. Nodular and orbicular chromite textures are known only from ophiolites and are interpreted to form during partial melting of flowing upper mantle, conditions needed to keep chromite suspended and growing concentrically into the magma. Minor orthopyroxene porphyroclasts with asymmetrical recrystallized tails and kink-banded olivine inclusions in chromite grains record plastic deformation and high-temperature shearing, before or during growth of the chromite. We attribute this deformation to flow in the Archean oceanic mantle. Later deformation is related to dismemberment of the ophiolite and incorporation into a mélange during collision of the Eastern and Western blocks of the North China craton. This collision formed the 1600km-long ophiolite-rich Central Orogenic

*Corresponding author: kusky@eas.slu.edu.

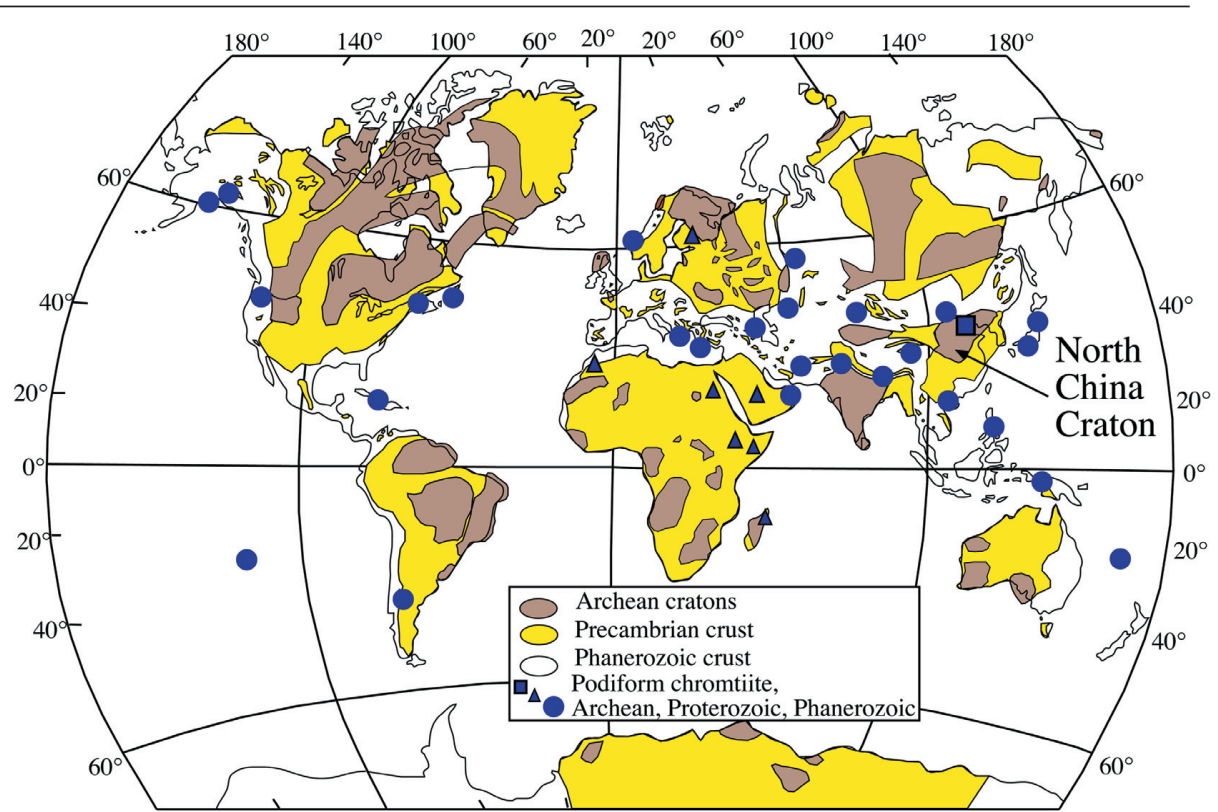

Figure 1. Distribution of Archean cratons, areas underlain by Precambrian crust, and Phanerozoic crust and podiform chromite deposits (modified after Kusky and Polat, 1999). Filled patterns show locations of major ophiolitic podiform chromite deposits in relation to crust and accretionary orogens of different ages. Squares_-Archean; triangles_-Proterozoic; circles—Phanerozoic. Zunhua podiform chromitites are associated with the 2.505 Ga Dongwanzi and related ophiolites of North China craton.

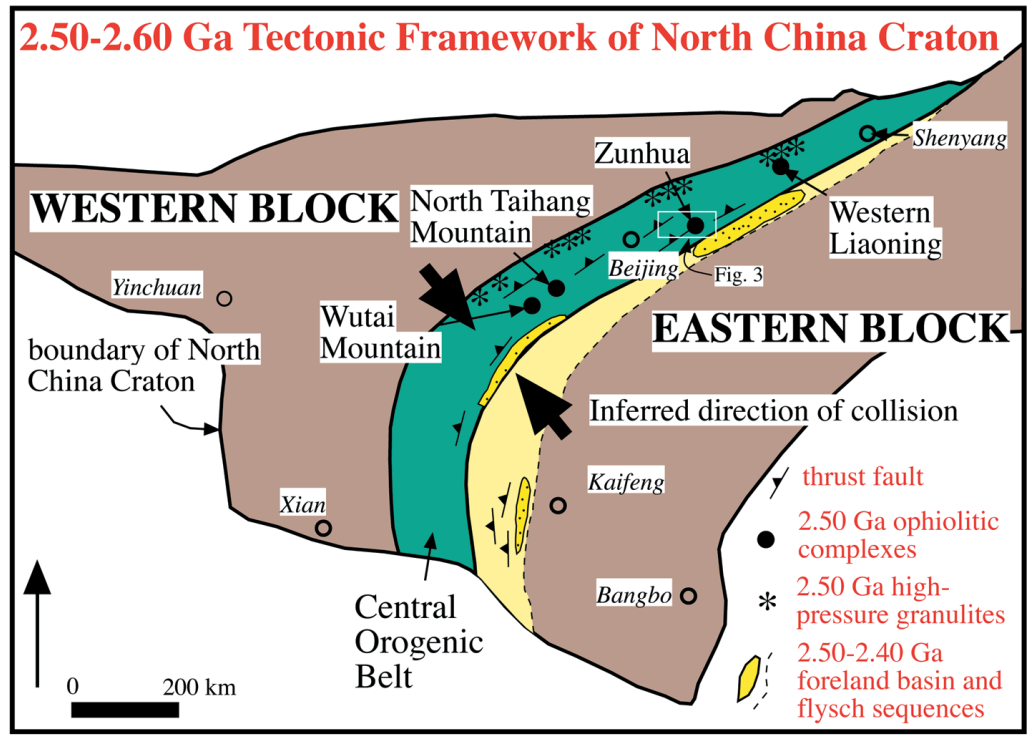

Figure 2. Tectonic map of North China craton showing division of North China craton into Eastern and Western blocks, separated by the Central Orogenic belt. (Modified after Li et al., 2000a, 2000b; Kusky et al., 2001). 
belt, and the 2.5-2.4 Ga Qinglong foreland basin and fold-thrust belt on the Eastern block, and provides an important record of the operation of plate tectonics in the Archean.

\section{INTRODUCTION}

Ophiolites are remnants of oceanic lithosphere that have been tectonically emplaced onto continents. They provide valuable information on the nature of seafloor processes, global heat loss, and paleogeographic reconstructions of the continents through ancient times. The question of whether ophiolites are present in the earliest rock record $(>2.0 \mathrm{Ga})$ is one of the most hotly debated scientific questions in early Earth history (Kusky and Polat, 1999; Karson, 2001). This is largely because until recently, complete ophiolite sections consisting of (in descending stratigraphic order) pillow lava, sheeted dike complex, gabbro, cumulate ultramafics, and tectonized mantle, had not been documented in rocks older than 2 Ga (Kontinen, 1987). The recently discovered $2.505 \mathrm{Ga}$ Dongwanzi ophiolite of the North China craton (Kusky et al., 2001) is a complete ophiolite, but most original mantle textures and mineral parageneses are overprinted. In this paper, we report newly discovered podiform chromitites from Archean mantle harzburgite tectonite and dunite host rocks that are $60 \mathrm{~km}$ southwest of and related to the complete Dongwanzi ophiolite. Podiform chromitites with nodularand orbicular-textured chromite balls in a harzburgite tectonite matrix are known only from ophiolitic settings (Fig. 1), and thus serve as a diagnostic marker of oceanic mantle, potentially as useful as the ophiolite suite itself for identifying fragments of ancient oceanic lithosphere and asthenosphere.

The 2.5 Ga Zunhua podiform chromitites have remarkably well preserved delicate magmatic and deformational textures that provide a glimpse into igneous and structural processes active in the suboceanic mantle in the Archean. These types of structures were known previously only from much younger oceanic mantle rocks and, thus, preserve a unique remnant of Archean oceanic mantle.

\section{GEOLOGICAL SETTING}

The North China craton is divided into two major blocks, the Western block and

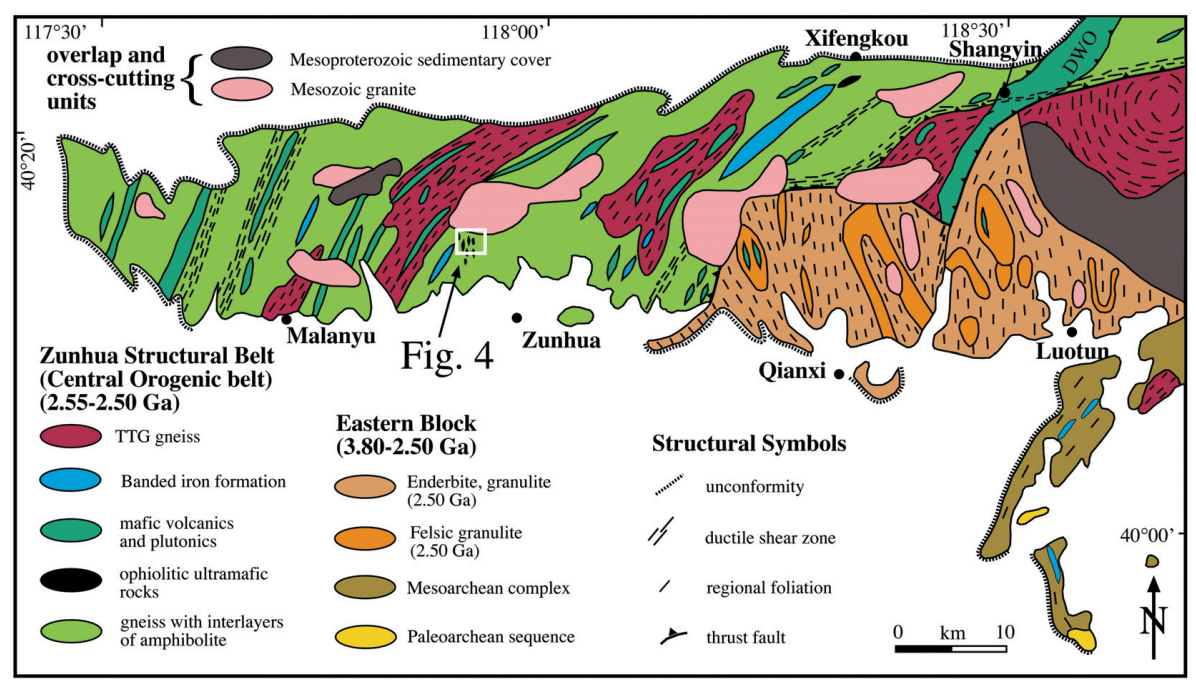

Figure 3. Structural sketch map showing distribution of Archean ophiolites and major structural boundaries of Zunhua Structural belt, eastern Hebei.

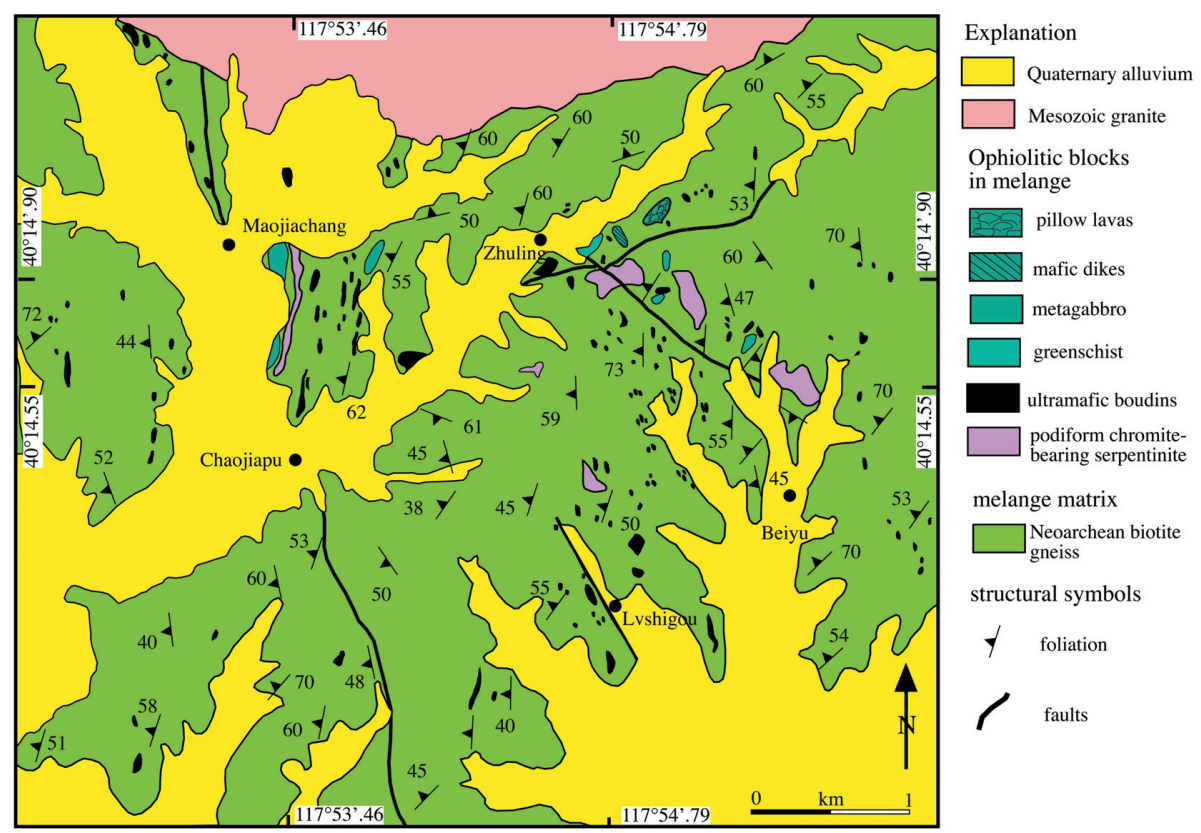

Figure 4. North Zunhua area showing distribution of ophiolitic blocks in a matrix of biotite gneiss and hornblende-biotite (modified from local geological maps and remapping by the authors).

the Eastern block, separated by the Neoarchean Central Orogenic belt that extends across the craton (Fig. 2). The Western block contains a thick platformal sedimentary cover (Ordos block) intruded by a narrow belt of $2.55-2.5 \mathrm{Ga}$ arc plutons along its eastern margin. The Eastern block contains a variety of ca. $3.80-2.5 \mathrm{Ga}$ gneissic rocks and greenstone belts locally overlain by $2.6-2.5 \mathrm{Ga}$ sandstone and carbonate. The $700-\mathrm{km}-$ long Hengshan high-pressure granulite belt $(2.5 \mathrm{Ga})$ is located along the western side of the Central Orogenic belt (Li et al., 2000a). Isotopic ages available from the Central Orogenic belt mainly range between 2.58 and $2.50 \mathrm{Ga}$ (Li et al., 2000a; Wu et al., 1998). A younger age peak of $1.90-1.80 \mathrm{Ga}$ is related to late tectonic extension (Li et al., 2000a). Central parts of the Central Orogenic belt include a complex assemblage of ca. 2.55-2.5 Ga deformed metavolcanic, metaplutonic, banded iron formation and metasedimentary rocks, intruded by ca. 2.5-2.4 Ga granite. A belt of 2.5-2.4 Ga 

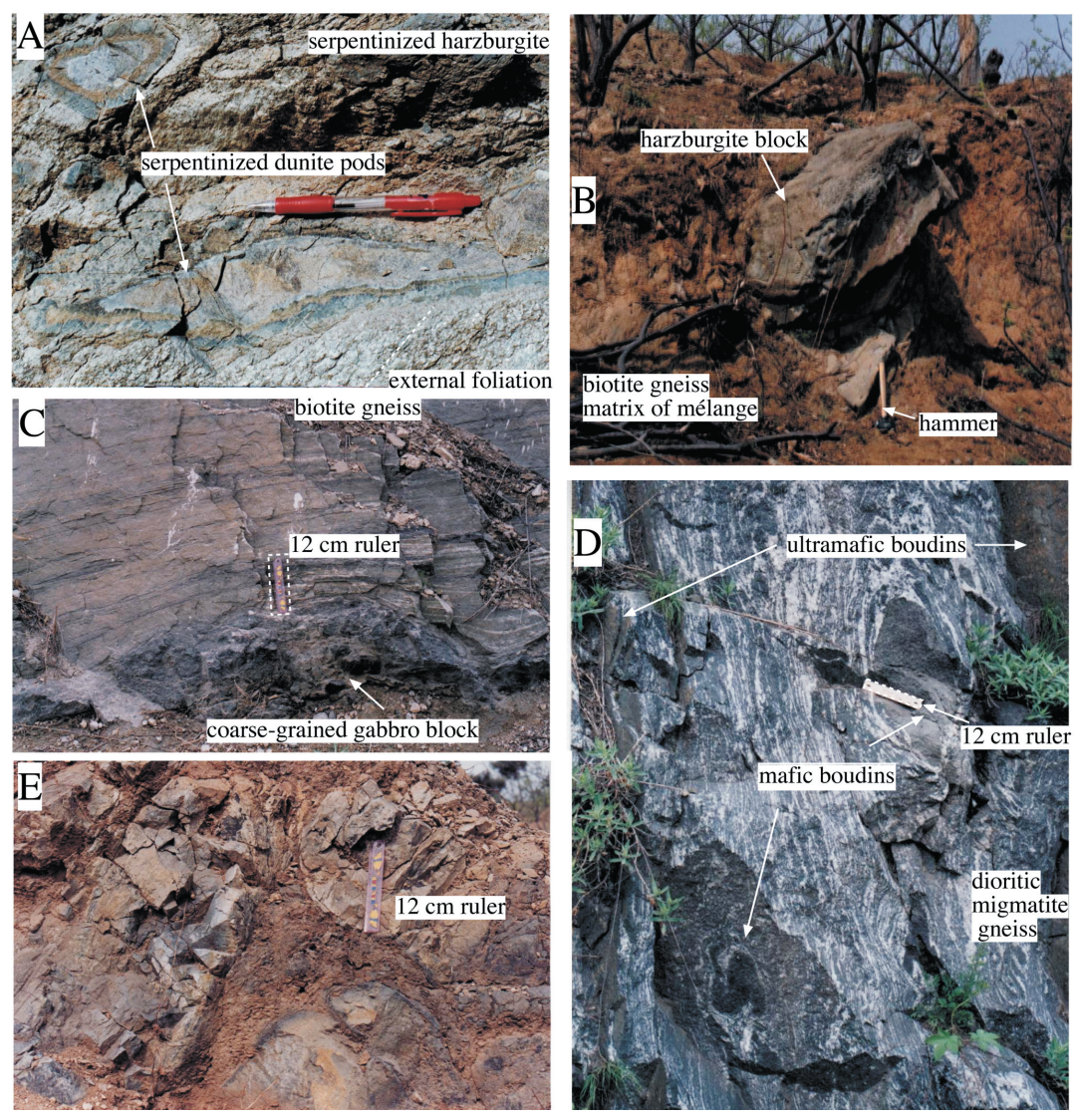

Figure 5. Field photos of podiform chromite and related outcrops, North Zunhua area. A. Flattened lenses and pods of dunite in a foliated serpentinized harzburgite matrix. B. Serpentinized harzburgite block in mélange, matrix of weathered biotite gneiss. C. Gabbroic block within sheared biotite gneiss. D. Mafic and ultramafic boudins as inclusions with dioritic gneiss. E. Pillow lava from block in mélange.

and granites are tectonically intercalated with each other (Kusky et al., 2001; Wu et al., 1998). More than 1000 ultramafic boudins have been recognized in the Zunhua structural belt, and these range from several meters to several kilometers in length (Figs. 3 and 4). These were intruded by ca. 2.56-2.5 Ga tonalitic gneiss, then 2.5-2.4 Ga granites (Wu et al., 1998).

Geochemical analyses reveal that mafic volcanics in the Zunhua structural belt have an oceanic affinity. They exhibit flat rare earth element to light rare earth element-depleted patterns that are similar to basalts from suprasubduction and mid-oceanic ridge settings (Wu et al., 1998; Zhao et al., 1993; Kusky and Li, 2002).

A complete $2.505 \mathrm{Ga}$ ophiolite has been described from the northeastern part of the Zunhua structural belt (Kusky et al., 2001). The Dongwanzi ophiolite is in the same belt as the ultramafic blocks described in this contribution,

weakly metamorphosed flysch and molasse basins that extends along the eastern margin of the Central Orogenic belt (Fig. 2) is interpreted here as remnants of a foreland basin related to the collision of the Western and Eastern blocks. Rocks in this belt, colloquially named the Qinglong foreland basin, are now deformed in an east-vergent fold-thrust belt.

The Zunhua structural belt is a mainly amphibolite-facies terrane in the northern sector of the Central Orogenic belt, separated from an Archean granulite-gneiss dome $(3.85-2.50 \mathrm{Ga})$ of the Eastern block by a major shear zone (Fig. 3). The Zunhua structural belt contains mainly northeast striking, intensely strained gneiss. Various thrust slices, including tonalite-trondhjemite-granodiorite gneiss, mafic plutonic rocks, supracrustal sequences,

Figure 6. Structures and microscopic textures of peridotite blocks in mélange. A, B. Polished surfaces of hand specimens illustrating principal textures of flattened harzburgite core with outer rings of serpentinite. Early high-temperature mantle-tectonite foliations are preserved in cores of pods. C. Harzburgite showing orthopyroxene (OPX), chromite (CMT), and olivine (OL) crystals (field of view is $3.2 \mathrm{~mm}$ horizontally). D. Asymmetrical olivine porphyroclast with recrystallized tail (outlined in white) within harzburgite tectonite (field of view is $3.2 \mathrm{~mm}$ horizontally). E, F. Kink bands within relict olivine (OL) in serpentinized harzburgite (field of view is $3.2 \mathrm{~mm}$ horizontally in both photomicrographs).
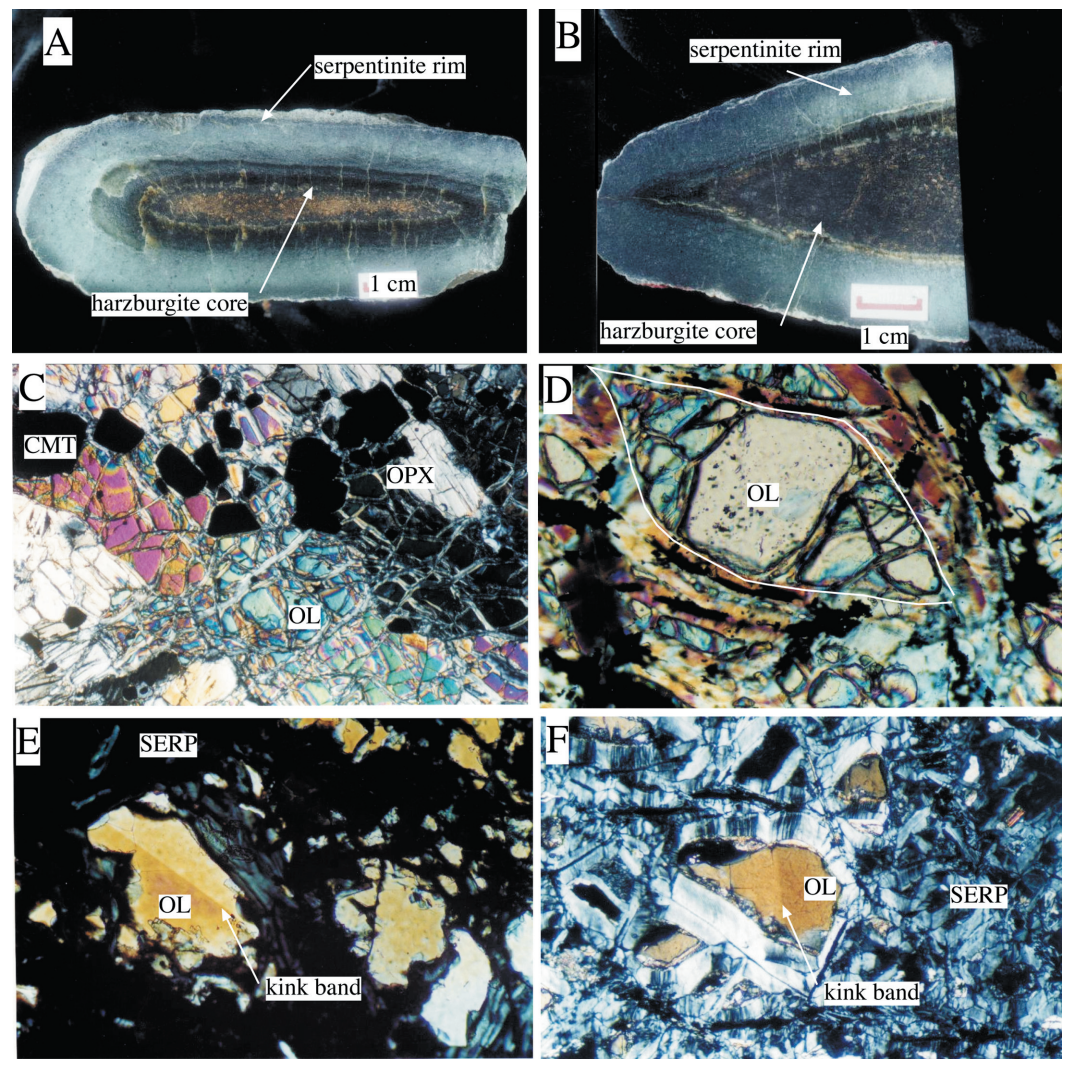
ophiolite may be interpreted as the largest block in the mélange that preserves preferentially the upper (crustal) part of the ophiolitic sequence. The blocks described here preserve deeper parts of the ophiolitic lithosphere than have so far been recognized in the Dongwanzi ophiolite.

\section{Ophiolitic mélange in the Zunhua structural belt}

Detailed field and petrographic analysis of mafic and ultramafic blocks in the southwestern Zunhua structural belt has revealed an assemblage of typical ophiolitic rock types. These include partly serpentinized harzburgite, peridotite tectonite, dunite, serpentinite, podiform chromitite, hornblendite, wehrlite, pyroxenite, metagabbro, cumulates and pillow lavas, massive metabasalt, and greenschist (Figs. 3 and 4). Locally, well-preserved sheeted dikes, layered gabbro, and cumulates are recognized. All these units are intruded by ca. 2.5-2.4 Ga granite (Wu et al., 1998), demonstrating their Archean ages. All the Archean units are overlain unconformably by ca. 1.85 Ga sedimentary cover.

Ultramafic and mafic pods and tectonic blocks are stretched and occur within a strongly deformed matrix of foliated and sheared, fine-grained biotitegneiss and hornblende-gneiss with some layers of amphibolite and banded iron formation (Figs. 3 and 5). These blocks are intensely sheared and tectonically transposed along their margins. In contrast, internal structures of the blocks commonly show distinct foliation and fold patterns, discordant to the external foliations outside the blocks in the surrounding shear zones. Gabbro and pyroxenite boudins (Fig. 5) exhibit well-preserved relict cumulate textures and cyclic cumulate banding of clinopyroxene, olivine, and plagioclase. Within the cores of peridotite blocks and pods, metamorphic tectonite fabrics are well preserved as oriented orthopyroxene porphyroclasts, strings of chromite, and elongated ribbons of olivine (Fig. 6). The early tectonic fabrics defined by compositional layering include chromite seams, disseminated chromite, oriented nodular chromite, and flattened antinodular chromite. In younger ophiolite complexes, these textures are generally interpreted to form during high-temperature $\left(>1000{ }^{\circ} \mathrm{C}\right)$ plastic deformation in the mantle (Nicolas and Arzi, 1991; Holtzman, 2000).

Late steeply dipping shear zones parallel to tectonic contacts with country rocks cut the early high-temperature-tectonite fabrics in the peridotite. Serpentinization is concentrated along late shear zones and fractures cutting across the earlier foliation. Within these shear zones, ultramafic protoliths are separated into numerous small-scale pods and lenses, which are further flattened and stretched. The late tectonic fabric and hydrous metamorphism that overprints the harzburgitic mantle tectonites probably occurred during obduction-related emplacement of the ophiolite in the Archean.
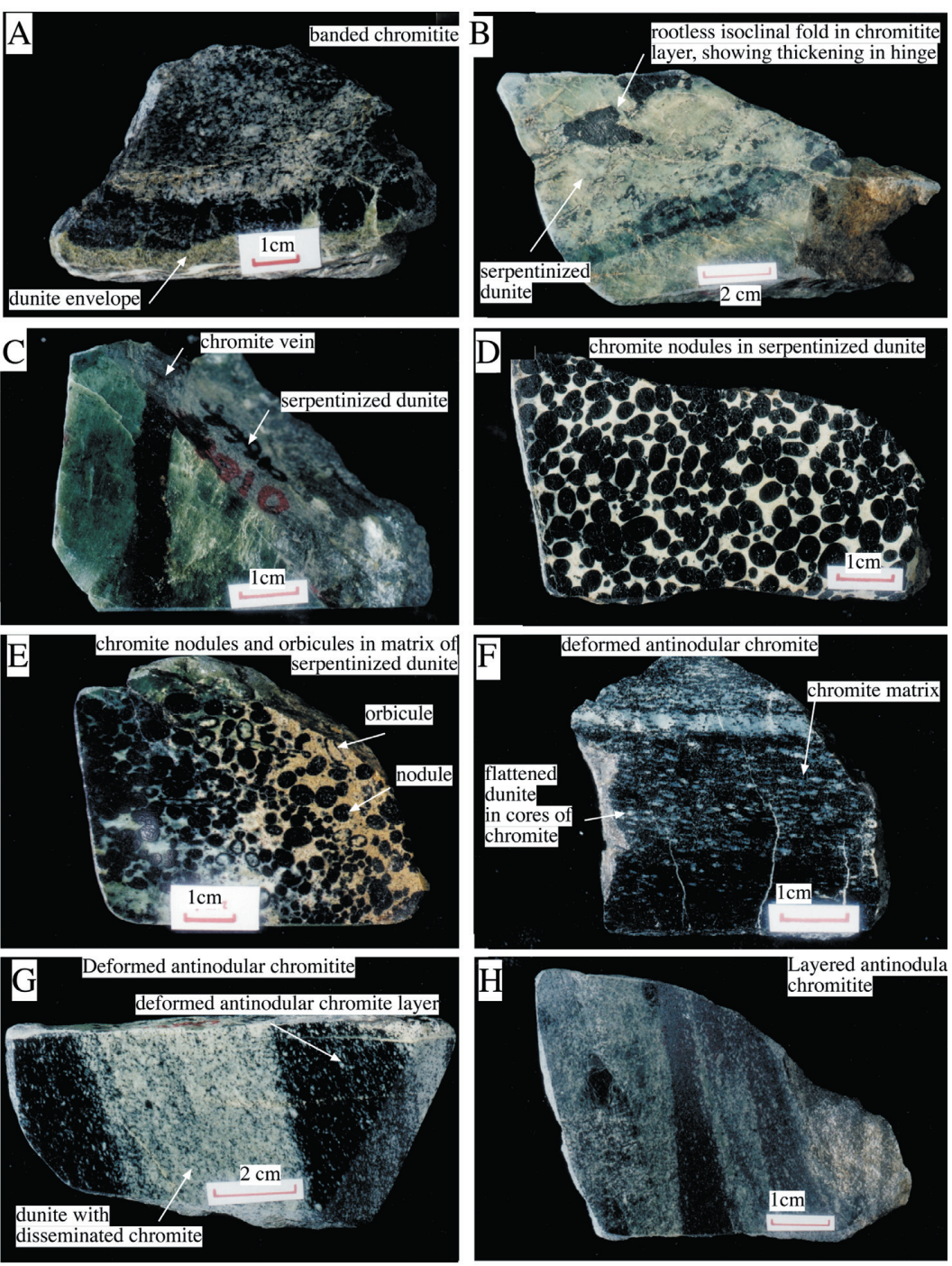

Figure 7. Polished surfaces of hand specimens illustrating principal microstructures and textures of chromitites ores. A. Banded chromitites with dunite envelop preserved at base of sample. B. Rootless fold showing thickening of chromitite band in a serentinized dunite matrix. C. Chromite vein within serpentinized dunite. D. Nodular ite in weakly deformed domain. E. Nodular and orbicular chromite. F, G. Antinodular chromite, showing flattening of dunite in cores of chromite rings. $\mathbf{H}$. Layered antinodular chromites.

\section{Ophiolitic crust and mantle blocks in mélange}

Peridotites in the Zunhua structural belt are mainly composed of serpentinized olivine, relict orthopyroxene, chromite, and minor magnetite (Fig. 6A, 6B, and 6C). Stretched orthopyroxene grains enclosed in a serpentinite matrix with ribbon-shaped tails form augen up to $2-3 \mathrm{~mm}$ in diameter. Some orthopyroxene porphyroclasts preserve embayed outlines due to corrosion by melt. Minor subhedral to euhedral chromite is present. Some peridotite tectonites show penetrative foliations and stretching lineations. High-temperature metamorphic tectonite fabrics defined by aligned and stretched olivine are well preserved in cores of blocks (Fig. 6D). Relict olivine forms extended ribbons with asymmetrical geometry. Augen of olivine exhibit deformational kink bands (Figs. 6E and 6F). These fabrics are attributed to high-temperature flow in the mantle. Olivine crystals are 


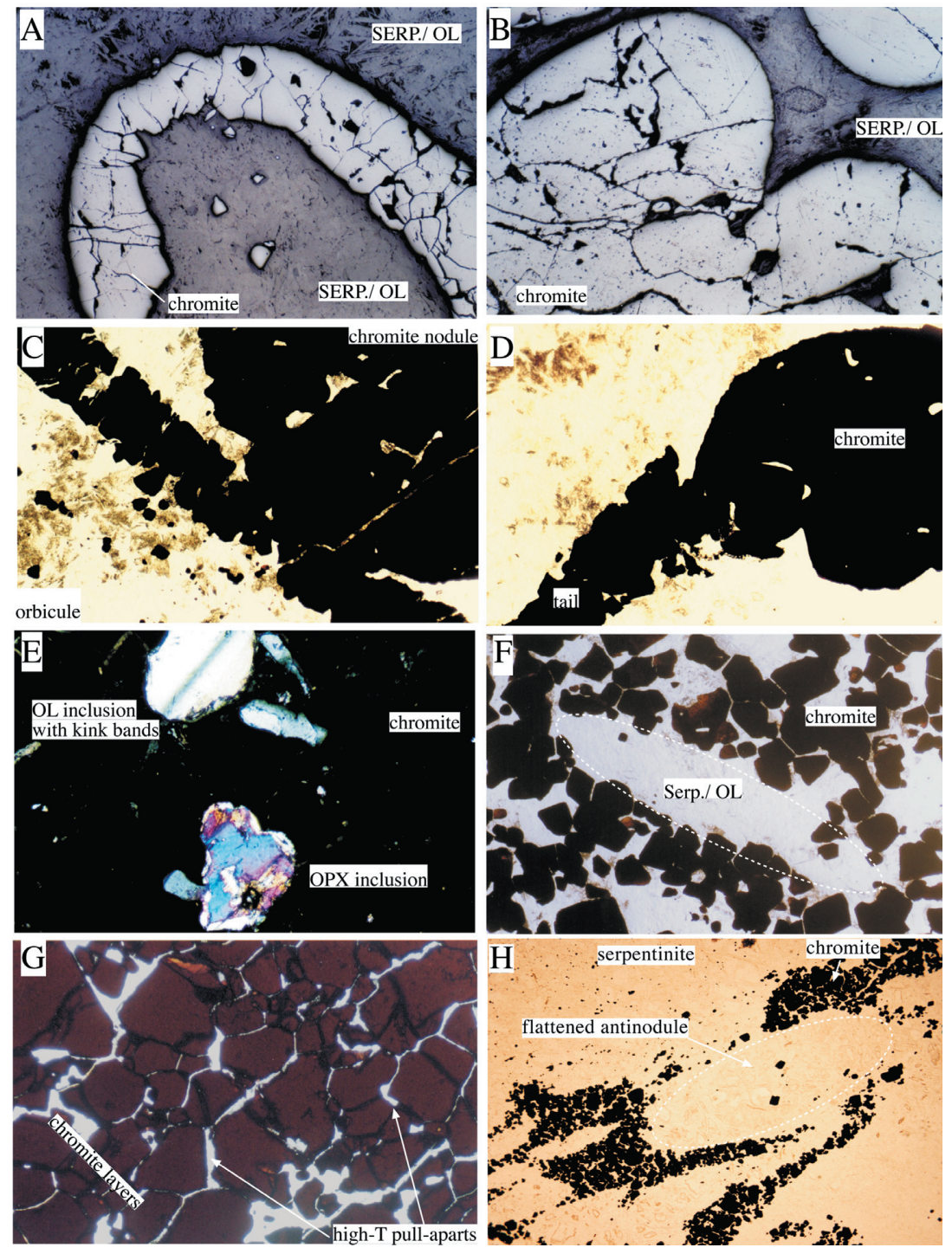

Figure 8. Microscopic textures of chromite ores. A. Flattened orbicule of chromite (reflected light). B. Flattened nodules of chromite and igneous contact between two nodules (reflected light). C. Flattening of contact between orbicule and nodule of chromite. D. Flattening of chrome nodule with asymmetrical tail. E. Inclusion of orthopyroxene $(\mathrm{OPX})$ and olivine $(\mathrm{OL})$ showing kink bands within chromites. F. Deformation textures of chromitite ore showing stretched olivine crystals in dunite core (strain ellipse outlined in white) with antinodular chromite. G. Pulled-apart chromites. H. Flattened antinodule forming concentrated bands of chrome and apparent folds from initial chrome network structure that originally surrounded antinodule. Field of view is $8 \mathrm{~mm}$ (horizontally) in A, $\mathrm{B}, \mathrm{C}, \mathrm{D}$, and $\mathrm{F}, 3.2 \mathrm{~mm}$ for $\mathrm{G}$, and $1.6 \mathrm{~mm}$ in $\mathrm{E}$ and $\mathrm{H}$.

commonly serpentinized, with magnetite distributed along the foliation planes.

Boudins and tectonic blocks of various types of gabbro and ultramafic cumulate within intensely sheared garnet-bearing gneiss range in size from a few centimeters to hundreds of meters. Rarely, pods of dunite are recognized within olivine gabbro (troctolite). These rocks are generally less deformed than the ultramafic rocks. Alternating pyroxene-rich and plagioclaserich modal and textural layering, $2-5 \mathrm{~cm}$ thick, locally preserve primary cumulate textures. The pyroxenite and olivine pyroxenite layers commonly transformed into foliated hornblendite along their margins as the gabbros underwent amphibolite-facies metamorphism.

Blocks of sheeted dikes, up to $100 \mathrm{~m}$ along strike, occur within the Zunhua structural belt (Fig. 4). The chilled margins are recognized as 2-3-cm-thick boundaries defined by strong alignment of fine-grained hornblende. They have only one chilled margin, which is a consequence of repeated intrusions in the center of a single opening fissure. The width of individual half-dikes is generally tens of centimeters. The mineral assemblage is plag $+\mathrm{cpx}+\mathrm{hb}$, characteristic of upper amphibolite facies conditions.

Spectacular pillow basalts are preserved locally in weakly deformed domains (Figs. 4 and $5 \mathrm{E})$. Pillows vary in size from tens of centimeters to one meter. Pillowed flows are interbedded with amygdular massive basalt. The pillow lavas are pervasively altered to albite and chlorite assemblages. Rarely, the pillows preserve dark cryptocrystalline margins, representing original glassy selvages. The shapes of pillows indicate younging toward the northwest. Layers of pillow breccia and volcanoclastic sediment are intercalated with the pillow basalt, and these units are metamorphosed to plagioclase-biotite schist and biotite schist. Some ultramafic lenses are intercalated with pillow lavas, indicative of large amounts of shearing (either on the seafloor or during emplacement).

At least six large and numerous smaller chromite-rich peridotite massifs are recognized within the southwestern Zunhua structural belt (Figs. 4 and 7). The chromitites are commonly lens shaped within dunite envelopes and are concordant with the foliation of the enclosing intensely serpentinized harzburgite.

Serpentinized pods and lenses show concentric rings with systematic variations in mineral composition and texture. Outer rings, commonly 2-10 cm thick, are composed of serpentine, whereas inner cores preserve dunite or massive harzburgite. Narrow, branching pyroxenite dikes (1-10 cm wide) are deformed within serpentinized harzburgite. The dikes are interpreted as channels of melt parental to oceanic basalt. Tectonic fabrics defined by folded chromite bands are well preserved in the cores of the serpentinized pods. Dunite envelopes are common features of podiform chromitites. They are known to form almost exclusively in the mantle or crust-mantle transition zone of suprasubduction zone (harzburgite type) ophiolites of different ages (Nicolas and Arzi, 1991; Zhou et al., 1996; Edwards et al., 2000).

Most of the chromitites are strongly deformed by high-temperature plastic flow, although nodular, orbicular, banded, massive, antinodular, and disseminated chromitite textures (sensu Johnston, 1936) are all locally preserved, especially in discordant pods (Fig. 7). Nodular textures consist of small balls of 
chromite in a dunite matrix (Fig. 8B, whereas orbicular chromites consist of thin rings of chromite surrounding rounded to flattened cores of dunite (Fig 8A). Nodular and orbicular chromites, with diameters of 2-10 $\mathrm{mm}$ and occasionally larger than $10 \mathrm{~mm}$, are generally flattened into elliptical shapes, and some orbicules form flattened rings. Nodular and orbicular textures are the most typical magmatic structures of ophiolitic chromitites (Nicolas, 1989; Nicolas and Arzi, 1991). Abundant deformed olivine occurs as inclusions in the chromite (Fig. $8 \mathrm{E})$, although they are widely altered into serpentine. Preliminary work on the crystallographic preferred orientations of olivine shows preferred slip on (010)[100] slip systems, which occurs at temperatures $>1200{ }^{\circ} \mathrm{C}$ (Nicolas, 1989).

Orthopyroxene porphyroclasts show asymmetrical recrystallized tails indicating high-temperature shearing.

Nodules are locally sorted into layers by their sizes. The nodules and orbicules show patterns of flattening and mutual impression along their contacts with each other (Figs. 8A, 8B, and 8C), suggesting that they settled while in a melt. These features are interpreted to be a result of rapid deposition of chromite nodules while they were still plastic. The nodules and orbicules commonly exhibit stretching fabrics (lineation and foliation), interpreted to have formed soon after crystallization, while the interstitial olivine was still in liquid form. Some are also elongated by plastic strain and show a preferred orientation. Most nodules are oriented parallel to the foliation. The outer boundary of single nodules is typically smooth and rounded (Fig. 8B). In contrast, the inner boundaries display individual chromite grains that grew inward (Fig. 8A). These textures are interpreted to record dynamic magmatic flow or partial melting conditions, needed to keep chromite suspended and growing concentrically into the magma. The delicate magmatic structures preserved show that they have not been significantly deformed after their formation, and they preserve the primary interaction between Archean melts and the upper mantle.

In some cases, nodules grade into antinodules in the same hand specimen. They record magmatic growth and settling in the upper mantle (e.g., Zhou et al., 1996; Edwards et al., 2000). Rounded

NW

2.55-2.50 Ga

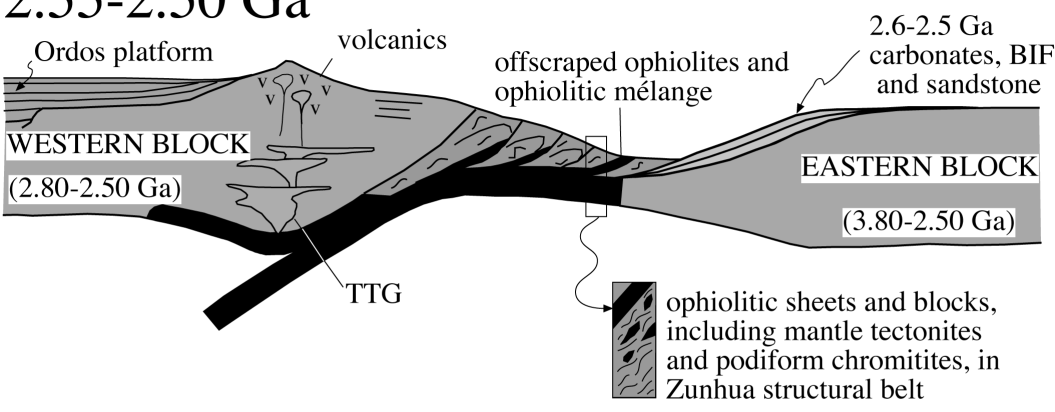

$2.50 \mathrm{Ga}$

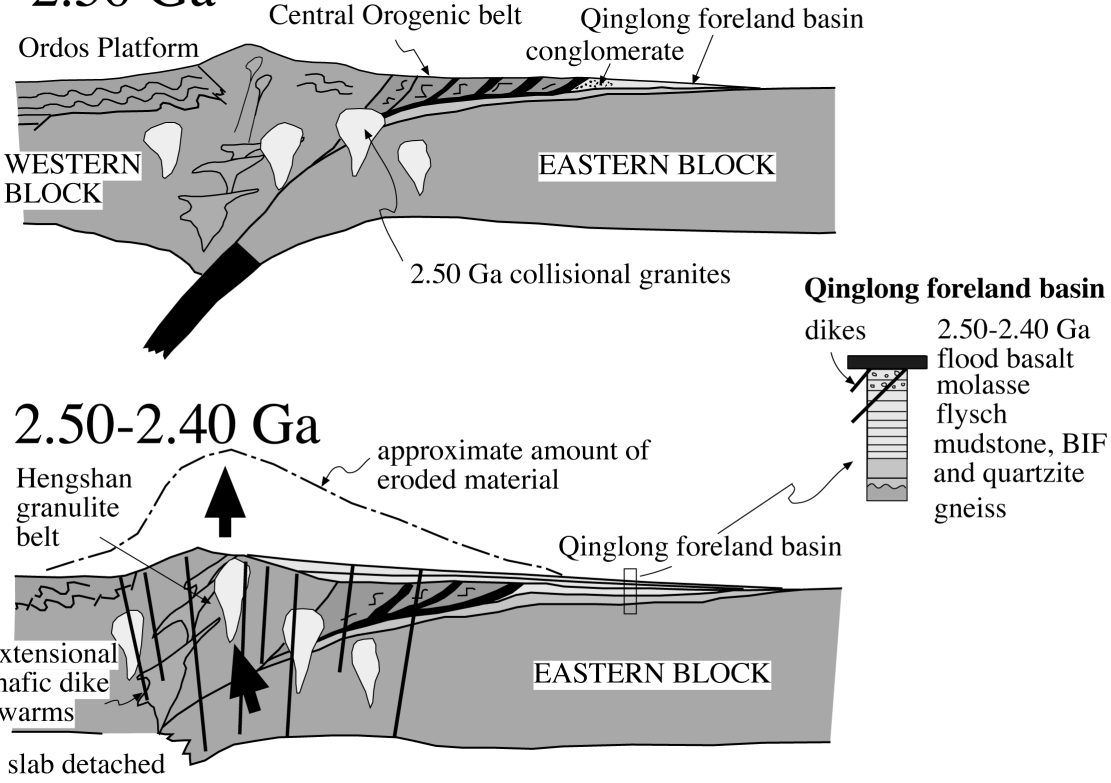

Figure 9. Model for the Late Archean tectonic evolution of the North China craton. An arc terrane built on the Western block at 2.55 Ga collides with the Eastern block at 2.5 Ga, forming an ophiolitic mélange with fragments of forearc and other ophiolites in an accretionary wedge during closure of the intervening ocean basin. The Central Orogenic belt overrides the passive margin of the Eastern block during attempted subduction of the margin of the Eastern block, forming the Qinglong foreland basin and foreland fold-thrust belt. Numerous 2.50-2.40 Ga granites intrude during and slightly after the collision. The partially subducted margin of the Eastern block rebounds isostatically and flexurally, causing the rapid uplift, extensional collapse, and exhumation of high-pressure granulites of the Hengshan belt at 2.5-2.4 Ga, along with the intrusion of an extensional mafic dikes swarm.

inclusions of olivine, orthopyroxene, and other silicates occur within chromite grains (Fig. 8E), and some inclusions of olivine show kink bands that record plastic deformation before or during growth of the chromite. A few fluid inclusions have also been observed within the silicate inclusions in chromite. These original magmatic structures are commonly destroyed with higher shear strain. For example, nodular and orbicular textures are strongly stretched and transposed into layering, folded bands, or antinodular chains. Compared with nodules, orbicules are more strongly stretched, their ratio of $\mathrm{X} / \mathrm{Z}$ being up to $5: 1$ (Figs $7 \mathrm{E}$ and $8 \mathrm{~A}$ ). We attribute this deformation to mantle flow in the oceanic mantle, as suggested for similar structures in many younger ophiolites (e.g., Nicolas, 1989).

Antinodular chromitites consist of flattened dunite aggregates with lengths of 2-10 $\mathrm{mm}$ surrounded by fine-grained chromite chains or flattened networks (Figs. 7, 8F, and 8H). Flattened antinodular texture is typical of high-temperature plastic deformation in oceanic mantle, which is a result of straining of weaker 
olivine inclusions in a rigid chromite-rich matrix. Alignment of needle-like chromite also indicates strong shearing. Layered and banded textures consist of anastomosing $2-4 \mathrm{~cm}$ thick bands and chains of chromite surrounding ovoids of olivine (Figs. $7 \mathrm{~F}$ and $7 \mathrm{H}$ ), which were generated by shearing of antinodular and nodular chromite layers, rather than by crystallization and accumulation. Tight folds are common in the banded chromitite. In a few places, narrow pyroxenite, dunite, and gabbroic dikes crosscut them. Some chromite layers occur as rootless folds or asymmetric lensoidal boudins, and other layers and lenses consist of nodules. Pullapart textures are common in the massive and layered chromitite deposits (Fig. 8G). These form extensional veins perpendicular to the chromite layers, filled by serpentinized dunite. Nicolas (1989) and Holtzman (2000) show that such textures form only at temperatures $>1000-1200{ }^{\circ} \mathrm{C}$.

\section{DISCUSSION AND CONCLUSIONS}

We interpret the mafic and ultramafic blocks in the biotite gneiss matrix to represent a strongly dismembered ophiolite in a metasedimentary and metavolcanic matrix. Relationships are strongly reminiscent of younger ophiolitic mélange terranes, where blocks of ophiolite are preserved in a metasedimentary accretionary prism and/or trench complex (e.g., Kusky et al., 1997). The Zunhua ophiolitic blocks in mélange do not preserve an overall younging direction, although a few of the blocks show younging directions toward the west. Similarly, the Dongwanzi ophiolite to the northeast preserves a westward-younging sequence.

These relationships suggest, although do not require, that the ophiolites were emplaced into the mélange during westward directed subduction, then thrust over the Eastern block during closure of the intervening ocean basin (Fig. 9). In this model the contemporaneous arc would be located to the west of the Zunhua structural belt. We interpret a narrow belt of deeply eroded and strongly metamorphosed $2.55-2.5 \mathrm{Ga}$ arc-type tonalite-trondhjemite-granodiorite plutonic rocks and a greenstone belt in the Wutai-Hengshan-Taihang Mountains to the southwest to represent the remnants of this arc (Li et al., 2000b; Wilde et al., 1998). The ca. 2.5-2.4 Ga
Qinglong, Hutuo, and Dengfeng sedimentary sequences and other similar basinal deposits east of the Central Orogenic belt (Figs. 2 and 9) may represent the foreland basin sequence resulting from the collision of the east and west blocks. These basin sequences consist of lower turbidite and upper molasse sequences, with more intense thrusting and folding in the west adjacent to the Central Orogenic belt. The 2.5-2.4 Ga granitoids that intrude the base of the ophiolite and much of the Central Orogenic belt could represent collisional-to-postcollisional granites formed during crustal thickening during orogenesis. This model also explains the exhumation of ca. 2.5 Ga high-pressure granulites and retrograde eclogites in the Hengshan belt to the west (Li et al., 2000a) (Fig. 9).

Harzburgite blocks in the mélange host podiform chromitites with dunite envelopes. The blocks grade up-section into wehrlite, pyroxenite, olivine gabbro (troctolite), and gabbro. Podiform chromitites are a normal component of ophiolites of different ages. They are located in the transition zone between layered gabbro and peridotite tectonite, and the lherzolite-harzburgite transition in ophiolites (Nicolas and Arzi, 1991). Their geological occurrence is closely associated with oceanic spreading processes (Nicolas and Arzi, 1991). Late Proterozoic podiform chromitites in ophiolites have been described in several areas, and Phanerozoic examples are numerous (Fig. 1). The oldest relatively intact podiform chromitite previously recognized is that from the Jourma and Outokumpu ophiolite complexes (2 Ga), Finland (Kontinen, 1987; Vuollo et al., 1995). The Zunhua chromite ores exhibit remarkable similarities to the podiform ores described from the examples mentioned above.

The Zunhua nodular and orbicular chromites are characteristic of alpinetype peridotites or ophiolitic chromite ores (Nicolas, 1989; Peters et al., 1991; Dilek et al., 2000). It is now believed that this type of chromite accumulated below the transition between oceanic crust and mantle based on numerous investigations in ophiolites. The origin of the podiform chromitites is attributed to melt-rock reaction, or dynamic magmatism within melt channels in the upper oceanic mantle (Nicolas and Arzi, 1991; Zhou et al., 1996). The presence of water in the melt is thought to be important for the formation of podiform chromite (e.g., Edwards et al., 2000). Inclusions within chromites, olivine, and orthopyroxene of the host peridotites in the Zunhua structural belt record high-temperature plastic deformation. The flattening and elongation of chromite parallel to foliation and lineation are indicators of intensive high-temperature shear strain. These textures probably record the plastic flow of the upper mantle, now mainly preserved in the core of tectonic blocks. These early lineations defined by deformed magmatic inclusions and the elongation of ore zones are not parallel to later lineations related to the emplacement of the blocks along shear zones, supporting the idea that they represent early mantle-deformation-related fabrics. Podiform chromitites are remarkably resilient to later deformation and metamorphism since they are generated at high temperatures (1200-1300 ${ }^{\circ} \mathrm{C}$ ) and become very rigid when cooled, thus resisting later shear. These asthenospheric chromite pods are miniature time capsules preserving extraordinary amounts of information about the Archean mantle that we have only begun to tap and understand.

Coupled with the presence of a full ophiolite sequence in the Dongwanzi complex, the documentation of the Zunhua chromitites provides evidence for the operation of seafloor spreading and plate tectonics during the Archean before $2.5 \mathrm{Ga}$. We prefer to ascribe a faster-to-moderate spreading rate to the formation of the Zunhua podiform chromitites, as podiform chromite is mainly associated with harzburgite-type ophiolites (Nicolas and Arzi, 1991). Although the field and petrographic observations are consistent with the Neoarchean ophiolites of the Central Orogenic belt preserving relatively hot mantle features, we do not have evidence that this mantle record was any hotter than the present-day range of mantle temperatures. However, the hot Archean North China mantle is consistent with some of the higher heat production during the Archean being accommodated by faster creation of oceanic lithosphere from a slightly hotter oceanic asthenosphere. 


\section{ACKNOWLEDGMENTS}

This research was supported by the National Science Foundation of China (No. 49832030), Peking University (Project 985), the U.S. National Science Foundation (Tectonics Program EAR-0221567), and by St. Louis University. Li thanks X.L. Qian for discussions and his extensive help. Jesse Dann, Claude Herzberg, John Encarnacion, and Igor Puchtel provided thoughtful reviews of this work. This is a contribution to International Geological Correlation Program Project 453.

\section{REFERENCES CITED}

Dilek, Y., Moores, E., Elthon, D., and Nicolas, A., 2000, Ophiolites and oceanic crust: New insights from field studies and the Ocean Drilling Program: Boulder, Colorado, Geological Society of America Special Paper 349, 552 p.

Edwards, S.J., Pearce, J.A., and Freeman, J., 2000, New insights concerning the influence of water during the formation of podiform chromitite, in Dilek, Y., et al., eds., Ophiolites and oceanic crust: New insights from field studies and the Ocean Drilling Program: Boulder, Colorado, Geological Society of America Special Paper 349, p. 139-147.

Holtzman, B., 2000, Gauging stress from mantle chromitite pods in the Oman ophiolite, in Dilek, Y., et al., eds., Ophiolites and oceanic crust: New insights from field studies and the Ocean Drilling Program: Boulder, Colorado, Geological Society of America Special Paper 349 , p. 149-158.

Johnston, W.D., Jr., 1936, Nodular, orbicular, and banded chromite in northern California: Economic Geology, v. 31, p. 417-427.

Karson, J.A., 2001, Oceanic crust when Earth was young: Science, v. 292, p. 1076-1078. Kontinen, A., 1987, An early Proterozoic ophiolite : The Jourma mafic-ultramafic complex, northeastern Finland: Precambrian Research, v. 35, p. 313-341.

Kusky, T.M., and Li, J.H., 2002, Is the Dongwanzi complex an Archean Ophiolite? (Response to Zhai, M., Zhao, G., and Zhang, Q.): Science, v. 295, p. A923.

Kusky, T.M., and Polat, A., 1999, Growth of granite-greenstone terranes at convergent margins and stabilization of Archean cratons: Tectonophysics, v. 305, p. 43-73.

Kusky, T.M., Li, J.H., and Tucker, R.T., 2001, The Dongwanzi Ophiolite: Complete Archean ophiolite with extensive sheeted dike complex, North China craton: Science, v. 292, p. 1142-1145.

Kusky, T.M., Bradley, D.C., Haeussler, P., and Karl, S., 1997, Controls on accretion of flysch and mélange belts at convergent margins: Evidence from the Chugach Bay thrust and Iceworm mélange, Chugach Terrane, Alaska: Tectonics, v. 16, p. 855-878.

Li, J.H., Kroner, A., and Qian, X.L., 2000a, The tectonic evolution of early Precambrian high-pressure granulite belt, North China Craton: Acta Geologica Sinica, v. 74, no. 2, p. $246-256$.

Li, J.H., Qian, X.L., and Huang, X.N., 2000b, The tectonic framework of the basement of North China craton and its implication for the early Precambrian cratonization: Acta Petrologica Sinica, v. 16, no. 1, p. 1-10 (in Chinese with English abstract).

Nicolas, A., 1989, Structures of ophiolites and dynamics of oceanic lithosphere: Dordrecht, Netherlands, Kluwer Academic Publishers, 367 p.

Nicolas, A., and Azri, H.A., 1991, Chromite-rich and chromite-poor ophiolites: The Oman case, in Peters, Tj., et al., eds., Ophiolite genesis and evolution of the oceanic lithosphere: Boston, Massachusetts, Kluwer Academic Publishers, p. 261-274.

Peters, Tj., Nicolas, A., and Coleman, R.G., 1991, Ophiolite genesis and evolution of the oceanic lithosphere: Boston, Massachusetts, Kluwer Academic Publishers, $903 \mathrm{p}$

Vuollo, J., Liipo, J., Nykanen, V., Piirainen, T., 1995, An early Proterozoic podiform chromitite in the Outokumpu ophiolite complex: Finland Economic Geology, v. 90, p. 445-452.

Wilde, S.A., Cawood, P.A., Wang, K.Y., Nemchin, A., 1998, SHRIMP U-Pb zircon dating of granites and gneisses in the Taihangshan-Wutaishan area: Implications for the timing of crustal growth in the North China craton: Chinese Science Bulletin, v. 43, p. 144-145.

Wu, J., Geng, Y.S., Shen, Q.H., 1998, Archean geology characteristics and tectonic evolution of Sino-Korea paleocontinent: Beijing, China, Geological Publishing House, p. 1-104 (in Chinese).

Zhao, Z.P., Cheng, D.M., and Li, Z.R., 1993, The Precambrian geological evolution of Sino-Korean paraplatform: Beijing, China, Science Publishing House, 1-83 (in Chinese).

Zhou, M.F., Robinson, P.T., Malpas, J., and Li, Z., 1996, Podiform chromitites in the Luobusa ophiolite (southern Tibet): Implications for melt-rock interaction and chromite segregation in the upper mantle: Journal of Petrology, v. 37, p. 3-21.

Manuscript received February 7, 2002; accepted April 30, 2002 